\title{
Biogeographical determinants for total and endemic species richness in a continental archipelago
}

\author{
A. S. Kallimanis $\cdot$ E. Bergmeier $\cdot$ M. Panitsa $\cdot$ K. Georghiou $\cdot$ \\ P. Delipetrou $\cdot$ P. Dimopoulos
}

Received: 16 March 2009/Accepted: 10 November 2009/Published online: 1 December 2009

(C) Springer Science+Business Media B.V. 2009

\begin{abstract}
We examined the relationship between plant species richness and biogeographical variables (island area, island maximum elevation, distance from nearest inhabited island, distance from nearest mainland) using a data set comprising 201 islands of the Aegean archipelago. We found that endemic species richness was strongly correlated to total species richness. Single-island endemic species richness was most strongly correlated to island maximum elevation, and then to island area, with an apparent small island effect for islands smaller than $47 \mathrm{~km}^{2}$. Total species richness was most strongly correlated to island area (with no apparent small island effect), and less strongly correlated to island maximum elevation. Distance from the mainland or other inhabited islands displayed limited predictive value in our data set. The slope of the relationship between species richness and geographical factors (island area, elevation, distance from island/mainland) was steeper for endemic species richness than for total richness. Finally, the different scales of endemicity (single-island endemics, island group endemics and Aegean regional endemics) displayed similar qualitative trends and only differed quantitatively. Thus, we conclude that different biogeographical factors act as drivers for total species richness than for endemic species richness.
\end{abstract}

Keywords Environment-diversity relationship · Endemic species richness · Aegean · Island biogeography

\footnotetext{
A. S. Kallimanis $(\bowtie) \cdot$ M. Panitsa $\cdot$ P. Dimopoulos

Department of Environmental and Natural Resource Management, University of Ioannina, Agrinio 30100, Greece

e-mail: akallim@cc.uoi.gr; kalliman@bio.auth.gr

E. Bergmeier

Albrecht von Haller Institute of Plant Sciences, Georg-August University of Göttingen,

Untere Karspüle 2, 37073 Göttingen, Germany

K. Georghiou · P. Delipetrou

Department of Botany, Faculty of Biology, National and Kapodistrian University of Athens, Panepistimiopolis, 15784 Athens, Greece
} 


\section{Introduction}

Regional and local endemic plant species account for a considerable proportion of the world's plant diversity and, due to their limited geographic and habitat range, many endemics face considerable extinction risk. It is crucial for their conservation to understand which factors influence endemic species richness.

While there is extensive literature on the relationship between species richness and environmental factors (such as soil, elevation, climate, land use, etc.) considerably less is known about the effect of these factors on endemic species richness (Willerslev et al. 2002; Ackerman et al. 2007). There are documented examples of the lack of congruence in the spatial pattern of total species richness with the richness of endemic or rare species (Orme et al. 2005; Lamoreux et al. 2006; Mazaris et al. 2008). This mismatch may reflect differences in recent environmental and palaeobotanical factors driving endemic species richness or biodiversity in general.

Most of the studies that have examined endemism on islands focused on oceanic islands, where endemism rates are particularly high (Groombridge 1992; Davis et al. 1994). Meanwhile, continental shelf islands sensu Whittaker and Fernandez-Palacios (2007), disconnected from each other and the mainland by rising sea level, provide perhaps the best natural laboratories to study the effects of geographical isolation on allopatric speciation via selection and/or genetic drift. Such continental islands allow insights into the evolution, distribution, colonization and dispersal of plant species and populations.

The Aegean is a continental archipelago which has experienced continuous human presence over the past several millennia. It has been the subject of biogeographical investigation since the first half of the twentieth century (Rechinger 1950; Rechinger and Rechinger-Moser 1951). As a result, the flora, endemism and phytogeography in the Aegean region are relatively well known (e.g., Greuter 1970, 1972; Runemark 1971a; Snogerup and Snogerup 1987; Strid 1996). These studies in the Aegean document the existence (a) of endemic relict species with no close relatives in the present flora and with a long paleobotanical history and (b) of endemic species that evolved comparatively recently and chiefly by non-adaptive radiation (Runemark 1969, 1970).

In the present study we examined the relationship between vascular plant species richness (both for all species and for endemic species) and biogeographic variables (such as island area, maximum elevation, distance from nearest inhabited island and distance from nearest mainland) on 201 islands of the Aegean archipelago.

The aim of the study was to examine: (a) if and how the geographic factors examined influence the endemic vascular species richness and (b) whether the relationship between total vascular species richness and environmental factors reflects accurately the relationship between these environmental factors and endemic species richness. This finding may allow us to tap into the existing knowledge regarding environmental drivers of species diversity.

For example, a common phenomenon concerning species richness is the small island effect. This predicts that as island area decreases, its effect on species diversity becomes insignificant and the species-area relationship disappears. In the Aegean, however, Panitsa et al. (2006) demonstrated that even for very small islets, the small island effect is not apparent. Can we therefore extrapolate from this finding and argue that the small island effect also does not hold for endemic species richness in the Aegean? 


\section{Methods}

Data set

The dataset used in this study consists of qualitative floristic data concerning 201 islands and islets throughout the Aegean. The islands and islets vary in size from 0.0004 to $8729 \mathrm{~km}^{2}$ and in elevation from 2 to $2456 \mathrm{~m}$ asl. The islands belong to five floristic regions (Strid 1996), with 97 in the East Aegean (EAe), 51 in the South Aegean (Kriti and Karpathos, KK), 29 in the Central Aegean (Kiklades, Kik), 20 in the West Aegean (WAe) and 4 in the North Aegean (NAe) (Fig. 1). The islands were assigned to island groups (Fig. 1) with each group consisting of neighbouring islands, e.g. a main island and its offshore islets.

Data concerning the total floras were obtained from the literature: Bazos (2005), Bergmeier and Dimopoulos (2001), Bergmeier (2002), Bergmeier et al. (2001), Brofas et al. (2001), Burton (1991), Carlström (1987), Christodoulakis (1986, 1996, 2000), Greuter et al. (1983), Höner (1991), Kamari et al. (1988), Panitsa and Tzanoudakis (1998, 2001), Panitsa

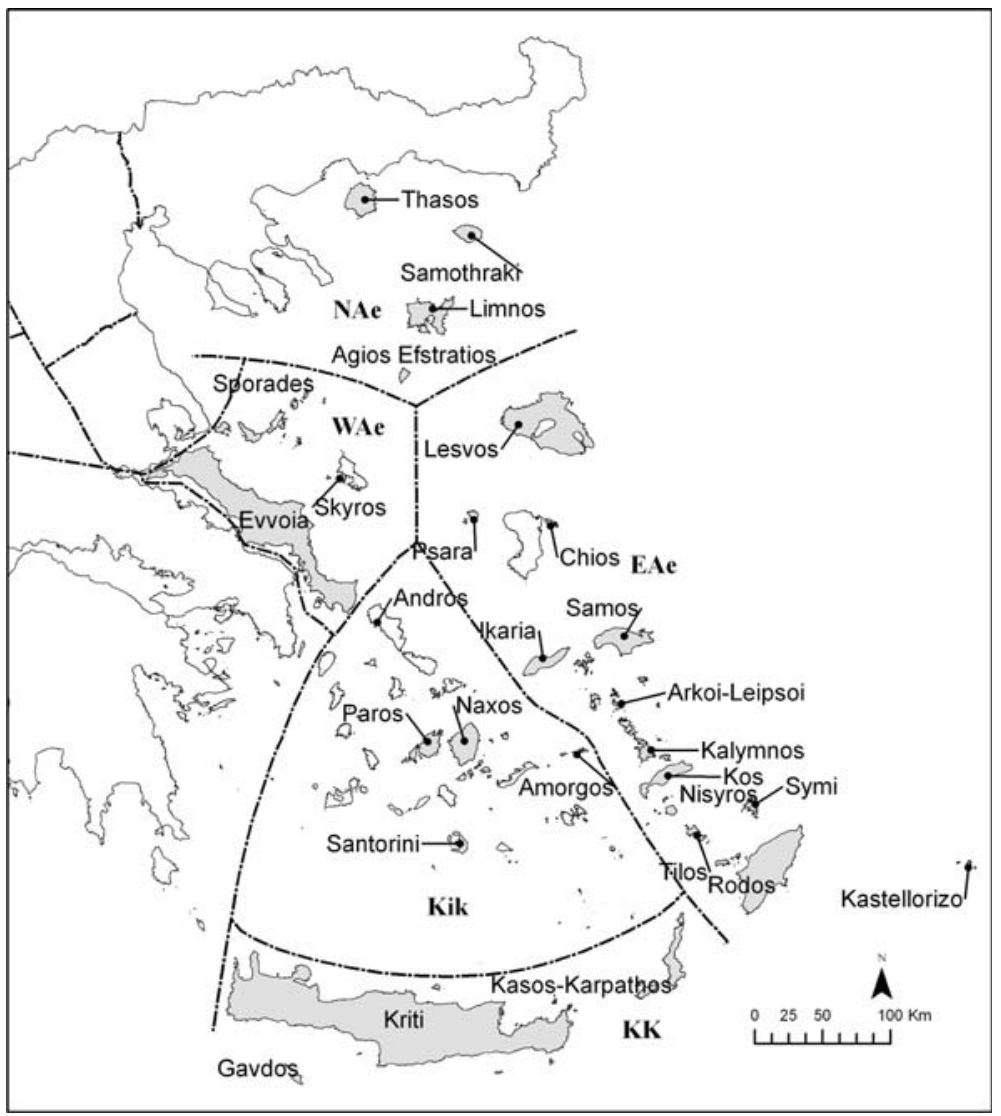

Fig. 1 Map of the Aegean archipelagos where the major islands are indicated, and the five floristic regions delineated. These regions are East Aegean (EAe), South Aegean (Kriti and Karpathos, KK), Central Aegean (Kiklades, Kik), West Aegean (WAe) and North Aegean (NAe) 
et al. (1994, 2003, 2004, 2006), Raus (1989, 1996a, b), Snogerup and Snogerup (1987, 1993), Snogerup et al. (2001), Strid and Tan (1998), Trigas and Iatrou (2006), Tzanoudakis et al. (2006). Data concerning the numbers of endemic species were obtained from the floristic-phytogeographical database "Chloris" created by the University of Athens (Georghiou and Delipetrou 2008).

The geographical data (area, elevation, distance from nearest mainland or inhabited island) were obtained from maps and data provided by the Hellenic Navy, the geological data (regarding lithology) were compiled from the Geological Map of Greece 1:500,000 scale, and in some cases from finer scale geological maps $(1: 50,000)$.

\section{Analysis}

We analyzed the relationship between species richness and endemic diversity. Species richness is the total number of vascular plant species known to be present on an island. Endemic diversity was expressed as the number of endemic species present on an island. Endemicity was assessed at different scales, as single-island endemics, as island group endemics, and as regional endemics, that is endemic to one of the five Aegean floristic regions. Each coarser scale of endemic species contained also the finer scale endemics. As only 19 islands contained single-island endemics, the analysis of single-island endemics was limited to these. The inclusion of the other islands as zero values increased the noise of our data set but did not affect the trends presented in this paper.

Besides pairwise correlations among the different aspects of diversity, we also calculated for each island the relationship between diversity and geographic variables: area, maximum elevation, distance from nearest inhabited island, distance from nearest mainland, geological diversity (number of strata), and an index of human impact. For the latter, combining our field notes, data from the literature as well as maps, demographic and agricultural information, a 6-point scale was created: 1: never inhabited, not known to have ever been used for livestock grazing, 2: never inhabited, seasonally grazed, 3: now uninhabited but populated and cultivated in former times, 4: now seasonally inhabited, with previously cultivated ground, slight tourist development, 5: permanent population of up to 5 or so hamlets, tourist impact, grazing, 6: permanent population of many villages, tourist impact, grazing.

Identifying the best mathematical formula to relate biogeographical variables to diversity measures is far from simple, even for well studied factors like island area (for example see Tjørve 2003; Scheiner 2003). So in order to avoid the problem of which is the most appropriate mathematical model for each biogeographical variable and each diversity measure, and to avoid issues arising from the fact that many of our variables are not normally distributed, we correlated them using the Spearman rank correlation coefficient.

\section{Results}

Out of 201 islands, 19 support single-island endemics, and 64 host regional endemics (Table 1). Table 1 shows also the minimum values of island area, elevation and distance from the mainland and other inhabited islands for islands that support endemic species as derived from this study. Examination of this shows that the distribution of endemics is clearly biased towards larger island area and maximum elevation, the minimum values of these increasing as the scale of endemicity becomes finer. It can also be deduced from 
Table 1 Minimum values of island area, elevation and distance from the mainland and other inhabited islands for islands that support species (either endemic or not)

\begin{tabular}{lllll}
\hline & All islands & $\begin{array}{l}\text { Islands with } \\
\text { Aegean regional } \\
\text { endemics }\end{array}$ & $\begin{array}{l}\text { Islands with } \\
\text { island } \\
\text { endemics }\end{array}$ & $\begin{array}{l}\text { Islands with } \\
\text { single-island } \\
\text { endemics }\end{array}$ \\
\hline Island area $\left(\mathrm{km}^{2}\right)$ & 0.0004 & 0.00125 & 0.0025 & 4.62 \\
Total species richness & 1 & 16 & 53 & 275 \\
Maximum elevation $(\mathrm{m})$ & 2 & 6 & 8 & 27 \\
Distance from island $(\mathrm{km})$ & 0.04 & 0.04 & 0.04 & 5.4 \\
Distance from mainland $(\mathrm{km})$ & 0.108 & 0.108 & 0.108 & 0.108 \\
Number of islands & 201 & 64 & 35 & 19 \\
\hline
\end{tabular}

The value presented is the minimum value observed for any island supporting at least one species from each category

Table 1 that distance from mainland is not a determining factor, since the island that is closest to the mainland (Evvoia) supports single-island endemics.

Table 2 presents the correlation coefficient between species richness (both total and endemic) and each of the geographical variables examined. Total species richness and regional endemic species richness were most strongly (positively) correlated to island area, to maximum elevation, and to the index of human presence, and less strongly but also significantly to geological diversity. Regional endemic species richness was also strongly positively correlated to total species richness. The richness of species endemic to an island group was most strongly correlated to island maximum elevation and to island area, then to total species richness and to the degree of human impact; all correlations were positive. Finally, single-island endemic species richness was most strongly correlated to island maximum elevation, then to total species richness and to island area; again all correlations were positive. Regional endemic species richness was positively correlated to the distance from the nearest inhabited island but negatively correlated to the distance from the

Table 2 Spearman rank correlation coefficients of all pairwise correlations between biodiversity and geographical variables

\begin{tabular}{lcccc}
\hline & All species & $\begin{array}{l}\text { Aegean regional } \\
\text { endemics }\end{array}$ & $\begin{array}{c}\text { Island group } \\
\text { endemics }\end{array}$ & $\begin{array}{l}\text { Single-island } \\
\text { endemics }\end{array}$ \\
\hline Number of islands & 201 & 64 & 35 & 19 \\
Maximum elevation & $0.753^{* *}$ & $0.660^{* *}$ & $0.685^{* *}$ & $0.803^{* *}$ \\
Island area & $0.885^{* *}$ & $0.658^{* *}$ & $0.639^{* *}$ & $0.671^{* *}$ \\
Index of human impact & $0.731^{* *}$ & $0.609^{* *}$ & $0.563^{*}$ & 0.451 \\
Number of geological substrata & $0.485^{* *}$ & $0.313^{*}$ & $0.351^{*}$ & $0.520^{*}$ \\
Latitude & -0.027 & 0.005 & -0.159 & -0.043 \\
Longitude & -0.077 & 0.026 & 0.310 & 0.044 \\
Distance to inhabited island & $0.388^{* *}$ & $0.328^{*}$ & 0.161 & 0.059 \\
Distance to mainland & -0.112 & $-0.175^{*}$ & -0.279 & -0.161 \\
Total species richness & & $0.683^{* *}$ & $0.612^{* *}$ & $0.728^{* *}$ \\
\hline
\end{tabular}

Statistically significant correlations are indicated by asterisk. ${ }^{*} P<0.05,{ }^{*} * P<0.001$ 


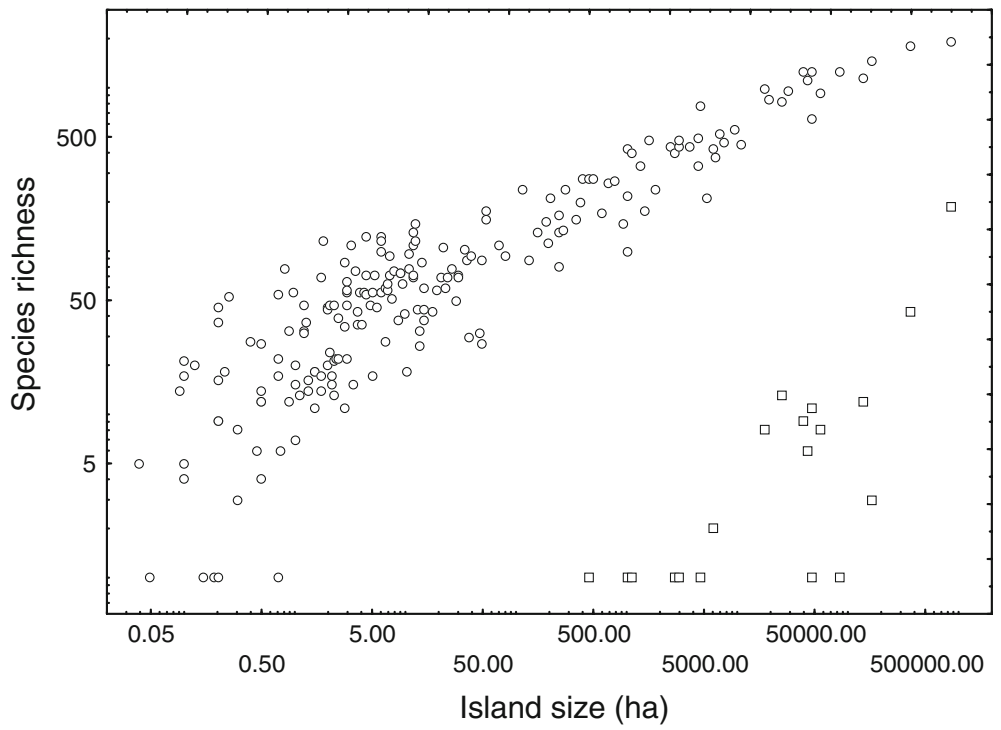

Fig. 2 The species-area relationship for total species richness (circles) and for single-island endemic species richness only (squares). Each point represents an island

mainland, while richness of single-island endemics and island group endemics was not correlated with distance from either the mainland or the nearest inhabited islands.

Figure 2 shows the species-area relationship for total species richness (circles) and for single-island endemics (squares). The small island effect was not observed for total species richness (species-area relationship), but for single-island endemics (endemics-area relationship) the effect was apparent (Fig. 2). Islands of less than $47 \mathrm{~km}^{2}$ in size supported only one endemic species (i.e. a tenfold increase in island size was not associated with any change in single-island endemic species richness). Figure 2 also shows that the slope of the species-area relationship was steeper for island endemics than for total species richness. The same qualitative differences are also observed for the relationship between species richness and elevation (data not shown).

\section{Discussion}

In our study we examined the endemic species richness in 201 islands and islets in the Aegean archipelago, a continental archipelago where distance from the mainland is no more than $260 \mathrm{~km}$ and with continuous human presence documented over several millennia. Under these conditions, isolation should be examined with caution. However, this archipelago supports hundreds of endemic species (310 single-island endemic species were included in this study). Single-island endemic species constitute about $10 \%$ of the flora of Crete (Turland et al. 1993; Jahn and Schönfelder 1995; Turland and Chilton 2008). For the remaining 18 islands with single-island endemics, these constitute up to $2.5 \%$ of the island flora. Only large (island area more than $4.62 \mathrm{~km}^{2}$ ) and high (maximum elevation more than $355 \mathrm{~m}$ asl with the exception of one island with only $27 \mathrm{~m}$ ) islands host single-island endemic species. Continuous human presence on an island does not seem to be related to single-island endemism, since all 19 islands with such local endemics also support 
permanent human settlements. Isolation from the mainland by large stretches of sea is similarly not a prerequisite for the presence of single-island endemics. Evvoia, a large island separated from the mainland by a narrow strait of only $100 \mathrm{~m}$, supports 42 singleisland endemic species.

Scaling up from single-island endemics to island group endemics and further to regional endemics, the minimum area values decrease. Even very small islands with an area of $1250 \mathrm{~m}^{2}$ support regional endemic species, but no single-island endemics. Perhaps the existence of endemics on such small islands and islets may be due to a metapopulation type phenomenon. Very small islands often have a high species turnover (Panitsa et al. 2008) and do not support long-term safe habitats where a single small population of a local endemic species can persist over long periods, however, these islands are recolonizable by endemic species from other islands. These endemics form part of a group of small island specialists in the Aegean (that also include non-endemics), which were discussed and listed in Rechinger and Rechinger-Moser (1951) and by Bergmeier and Dimopoulos (2003).

Whatever the minimum requirements for a continental island to support endemic species are, the identity of the environmental factors affecting endemicity and especially single-island endemicity is even more intriguing. We found single-island endemic species richness to be most closely correlated to island maximum elevation. This was also observed for island group endemics, but the slope of the correlation was less steep. The primary importance of an island's maximum elevation for endemic species richness has also been recorded for endemic orchids in the West Indies (Ackerman et al. 2007).

Among the possible explanations for this relationship are habitat diversity, human disturbance, habitat stability and refugia during past climate change. Firstly, increased habitat diversity corresponds to increased availability of ecological niches to allow speciation of new endemic species. Kohn and Walsh (1994) and Ricklefs and Lovette (1999) reported a correlation between an island's maximum elevation and its habitat diversity. Secondly, all islands that support single-island endemics also support permanent human populations. However, we regard the possible conclusion that human disturbance and pressure induced speciation of single-island endemics as a logical error (cum hoc ergo propter hoc) with no causality between the two. Thirdly, higher elevation is a precondition for long-term stable ecosystems such as cliffs which support plant assemblages with high proportion of narrow endemics. Fourthly, a large elevational range may allow the vertical migration during periods of climate change, allowing the persistence of relictual populations of ancient species.

The habitat diversity explanation assigns a major role to speciation through adaptive radiation, while the latter two explanations assign greater importance to the persistence of older species or to speciation through non-adaptive radiation. In the Aegean, there are documented examples of endemic species associated with non-adaptive radiation (see Gittenberger 1991 for land snails; Snogerup 1967a, b and Barrett 1996 for the genus Erysimum, Strid 1970 and Bittkau and Comes 2005 for the Nigella arvensis complex, Runemark 1980 for the Dianthus fruticosus complex, Snogerup et al. 1990 for Brassica, Turland 1992 for the Dianthus juniperinus complex). Non-adaptive radiation attributable to stochastic mechanisms such as genetic drift, acting on small isolated populations, plays a primary role in speciation and endemism in the Aegean archipelago (Runemark 1969, 1971a). However, it has to be stressed that these possible explanations are not mutually exclusive, and there is no reason to assume that they do not act synergistically to enhance endemic species richness.

The relationship between total species richness on islands and environmental factors (mainly area, isolation, elevation and climate) has been studied extensively over the past 
century and a half (reviewed by Whittaker and Fernandez-Palacios 2007). Willerslev et al. (2002) reported that the ranking in relative importance of area, elevation and distance from mainland and other islands is the same for total and endemic plant species richness in the Galapagos. However, in the case of the Aegean archipelago (a continental archipelago where endemics represent a considerably smaller proportion of the flora), we get very different results regarding the diversity-environment relationship. Total species richness is most strongly correlated to island area and to the interaction between area and elevation. The latter could also be viewed as an index of area that takes into account the ruggedness of the terrain. However, area is less important to endemic species richness than elevation, as explained above. The two parameters (area and elevation) are correlated themselves and this may explain the correlation between total and endemic species richness.

As some of the larger (and higher) islands which are relatively rich in narrow endemics are located at the margins of the Aegean Sea rather than in its centre, it is plausible that no correlation was found between the richness of narrow endemics of an island and its distance from the mainland. Aegean regional endemic species richness, while positively correlated to the distance from the nearest inhabited (i.e., major) island, is negatively correlated to the distance from the mainland. This emphasizes the exceptional phytogeographic position of the central Aegean (viz. Kiklades) and the south Aegean (Cretan area) which are rich in regional endemics and more isolated from the mainland. Runemark (1971a, b, c), when focusing on the geological history of the Aegean area, showed that a great number of species that are common and evenly distributed in surrounding regions, are irregularly distributed in the Aegean.

Not only does the relative importance of the different factors differ between total and endemic species richness, but there are also qualitative differences between the two. For example, the index of human presence is positively correlated to total species richness (and to Aegean regional endemic species richness) but it is not correlated to single-island endemic species richness. This is all the more remarkable as single-island endemic species occur on sizable islands rather than on small uninhabited ones. A possible explanation for this may be the fact that a major part of the total flora consists of species that may be termed synanthropic in its wider sense, i.e. occurring in man-made habitats or in others more or less affected by livestock (Greuter 1995, 2001; Bergmeier and Dimopoulos 2003). This includes most annuals. The number and proportion of such species on Aegean islands increases with grazing (Bergmeier and Dimopoulos 2003) and, we may safely assume, with human impact in general. Such species, on the other hand, are rare among the narrow endemics. Greuter $(1979,1995,2001)$ stressed the importance of synanthropic plants for the Mediterranean islands, estimating the proportion of old introductions to some Aegean islands to be one-third or more of the total flora. He underlined the particularly long-lasting human influence and noted that synanthropic species, especially those already introduced in prehistoric or early historic times, may be perfectly integrated into native plant communities.

Another mismatch is the small island effect. Panitsa et al. (2006) could not identify a small island effect for the small islets of the Aegean and report that all islets with area $<0.05 \mathrm{~km}^{2}$ may behave idiosyncratically. The islets in our study lack single-island endemics, but among the larger islands that do support such endemics, the small island effect is pronounced. Six islands, having a wide range of area sizes $\left(4.6-47 \mathrm{~km}^{2}\right)$, supported only one endemic species. As the scale of endemicity coarsened the small island effect persisted, though the threshold dropped to smaller island areas. Our findings are in accordance with Ackerman et al. (2007) who found a similar "small island effect" for orchid endemic species richness, but on considerably larger islands (islands smaller than $750 \mathrm{~km}^{2}$ ). The 
main reason for this difference in the threshold value might be attributed to the fact that they examined only orchids and not endemism in general.

Finally, besides the qualitative differences, there are also quantitative differences when comparing the relationship between total diversity and environmental factors with the relationship between endemic species diversity and these factors. More specifically, as the scale of endemicity becomes finer, the slope of the relationship becomes steeper. This is in accordance with the findings of Triantis et al. (2008) that the endemic species-area relationship resembles the inter-provincial species-area relationship.

In conclusion, we caution against the use of total species richness as a surrogate of endemic species richness, when trying to identify the role of environmental factors for endemic diversity, despite the strong correlation between total and endemic species richness. For endemic species richness, elevation plays the more critical role, while for total species richness area, topography and human impact are important. Furthermore, there are significant qualitative differences, with endemic species displaying the small island effect whilst total species richness does not.

Acknowledgements We are indebted to two anonymous reviewers for valuable comments on an earlier version of the manuscript and to Laura Sutcliffe for linguistic improvements.

\section{References}

Ackerman JD, Trejo-Torres JC, Crespo-Chuy Y (2007) Orchids of the West Indies: predictability of diversity and endemism. J Biogeogr 34:779-786

Barrett SCH (1996) The reproductive biology and genetics of island plants. Philos Trans R Soc Lond B $351: 725-733$

Bazos I (2005) Study of the flora and vegetation of Lesvos. PhD thesis, University of Athens, Greece. (In Greek with an English summary)

Bergmeier E (2002) The vegetation of the high mountains of Crete-a revision and multivariate analysis. Phytocoenologia 32:205-249

Bergmeier E, Dimopoulos P (2001) Changes and limits of floristic island inventories-the Dionysades group (South Aegean, Greece) revisited. Phyton 41:277-293

Bergmeier E, Dimopoulos P (2003) The vegetation of islets in the Aegean and the relation between the occurrence of islet specialists, island size, and grazing. Phytocoenologia 33:447-474

Bergmeier E, Kypriotakis Z, Jahn R et al (2001) Flora and phytogeographical significance of the islands Chrisi, Koufonisi and nearby islets (S Aegean, Greece). Willdenowia 31:329-356

Bittkau C, Comes HP (2005) Evolutionary processes in a continental island system: molecular phylogeography of the Aegean Nigella arvensis alliance (Ranunculaceae) inferred from chloroplast DNA. Mol Ecol 14:4065-4083

Brofas G, Karetsos G, Panitsa M et al (2001) The flora and vegetation of Gyali island, SE Aegean, Greece. Willdenowia 31:51-70

Burton RM (1991) A check-list and evaluation of the flora of Nisiros (Dodecanese, Greece). Willdenowia 20:15-38

Carlström A (1987) A survey of the flora and phytogeography of Rodhos, Simi, Tilos and the Marmaris Peninsula (SE Greece, SW Turkey). PhD thesis, University of Lund, Sweden

Christodoulakis D (1986) Flora and vegetation of Samos. PhD thesis, University of Patras, Greece. (In Greek with an English summary)

Christodoulakis D (1996) The flora of Ikaria (Greece, E. Aegean Islands). Phyton 36:63-91

Christodoulakis D (2000) The flora of Samiopoula (E Aegean Islands, Greece): a biological, chorological and ecological analysis. Bot Chron 13:287-301

Davis SD, Heywood VH, Hamilton AC (1994) Centers of plant diversity: a guide and strategy for their conservation. WWF and IUCN, Cambridge

Georghiou K, Delipetrou P (2008) Database «Chloris»: endemic, rare, threatened and protected plants of Greece. Synonyms, distribution, conservation and protection status, biology, ecology, bibliography. University of Athens 
Gittenberger E (1991) What about non-adaptive radiation? Biol J Linn Soc 43:263-272

Greuter W (1970) Zur Paläogeographie und Florengeschichte der südlichen Ägäis. Feddes Repert 81: 233-242

Greuter W (1972) Betrachtungen zur Pflanzengeographie der Südägäis. In: Strid A (ed) Evolution in the Aegean. Opera Bot 30:49-64

Greuter W (1979) The origins and evolution of island floras as exemplified by the Aegean archipelago. In: Bramwell D (ed) Plants and islands. Academic Press, London, pp 87-106

Greuter W (1995) Origin and peculiarities of Meditteranean island floras. Ecol Mediterr 21(1-2):1-10

Greuter W (2001) Diversity of Mediterranean island floras. Bocconea 13:55-64

Greuter W, Pleger R, Raus T (1983) The vascular flora of the Karpathos island group (Dodecanesos, Greece). A preliminary checklist. Willdenowia 13:43-78

Groombridge B (1992) Global biodiversity: status of the Earth's living resources. Chapman \& Hall, London

Höner D (1991) Mehrjährige Beobachtungen kleiner Vegetationsflächen im Raume von Karpathos (Nomos Dhodhekanisou, Griechenland). Diss Bot 173:1-185

Jahn R, Schönfelder P (1995) Exkursionsflora für Kreta. Ulmer, Stuttgart

Kamari G, Phitos D, Snogerup B et al (1988) Flora and vegetation of Yioura, N Sporades, Greece. Willdenowia 17:59-85

Kohn DD, Walsh DM (1994) Plant species richness-the effect of island size and habitat diversity. J Ecol 82:367-377

Lamoreux JF, Morrison JC, Ricketts TH et al (2006) Global tests of biodiversity concordance and the importance of endemism. Nature 440:212-214

Mazaris A, Tzanopoulos J, Kallimanis A et al (2008) The contribution of common and rare species to plant species richness patterns: the effect of habitat type and size of sampling unit. Biodivers Conserv 17:3567-3577

Orme CDL, Davies RG, Burgess M et al (2005) Global hotspots of species richness are not congruent with endemism or threat. Nature 436:1016-1019

Panitsa M, Tzanoudakis D (1998) Contribution to the study of the Greek flora: flora and vegetation of the E Aegean islands Agathonisi and Pharmakonisi. Willdenowia 28:95-116

Panitsa M, Tzanoudakis D (2001) A floristic investigation of the islet groups Arki and Lipsi (East Aegean area, Greece). Folia Geobot 36:265-279

Panitsa M, Dimopoulos P, Iatrou G et al (1994) Contribution to the study of the Greek flora: flora and vegetation of the Enousses (Oinousses) islands (E Aegean area). Flora 189:367-374

Panitsa M, Snogerup B, Snogerup S et al (2003) Floristic investigation of Lemnos island (NE Aegean area, Greece). Willdenowia 33:79-105

Panitsa M, Bazos I, Dimopoulos P et al (2004) Contribution to the study of the flora and vegetation of the Kithira island group: offshore islets of Kithira (S Aegean, Greece). Willdenowia 34:101-115

Panitsa M, Tzanoudakis D, Triantis K et al (2006) Patterns of species richness on very small islands: the plants of the Aegean archipelago. J Biogeogr 33:1223-1234

Panitsa M, Tzanoudakis D, Sfenthourakis S (2008) Turnover of plants on small islets of the eastern Aegean Sea within two decades. J Biogeogr 35:1049-1061

Raus T (1989) Die Flora von Armathia und der Kleininseln um Kasos (Dodekanes, Griechenland). Bot Chron 9:19-39

Raus T (1996a) Additions and amendments to the flora of the Karpathos island group (Dodekanesos, Greece). Bot Chron 12:21-53

Raus T (1996b) Flora von Paros und Antiparos (Kykladen, Griechenland). Ann Naturhist Mus Wien 98(B Suppl):237-278

Rechinger KH (1950): Grundzüge der Pflanzenverbreitung in der Ägäis I-III. Vegetatio 2:55-119, 239-308, $365-386$

Rechinger KH, Rechinger-Moser F (1951) Phytogeographia Aegaea. Akad. Wiss. Wien, Math. Naturwiss Kl. Denkschr 105:1-208

Ricklefs RE, Lovette IJ (1999) The roles of island area per se and habitat diversity in the species-area relationships of four Lesser Antillean faunal groups. J Anim Ecol 68:1142-1160

Runemark H (1969) Reproductive drift, a neglected principle in reproductive biology. Bot Nat 122:90-129

Runemark H (1970) The role of small populations for the differentiation in plants. Taxon 19:196-201

Runemark H (1971a) The phytogeography of the central Aegean. In: Strid A (ed) Evolution in the Aegean. Opera Bot 30:20-28

Runemark H (1971b) Investigations of the flora of the central Aegean. Boissiera 19:169-179

Runemark H (1971c) Distributional patterns in the Aegean. In: Davis PH, Harper PC, Hedge JC (eds) Plant life of SW Asia. Botanical Society of Edinburgh, pp 3-12 
Runemark H (1980) Studies in the Aegean flora XXIII. The Dianthus fruticosus complex (Caryophyllaceae). Bot Nat 133:475-490

Scheiner SM (2003) Six types of species-area curves. Glob Ecol Biogeogr 12:441-447

Snogerup S (1967a) Studies in the Aegean Flora VIII. Erysimum Sect. Cheiranthus. A. Taxonomy. Opera Bot $13: 1-70$

Snogerup S (1967b) Studies in the Aegean Flora IX. Erysimum Sect. Cheiranthus. B. Variation and evolution in the small population system. Opera Bot 14:1-86

Snogerup S, Snogerup B (1987) Repeated floristical observations on islets in the Aegean. Plant Syst Evol 155:143-164

Snogerup S, Snogerup B (1993) Additions to the flora of Samos, Greece. Flora Mediterr 3:211-222

Snogerup S, Gustafsson M, von Bothmer R (1990) Brassica sect. Brassica (Brassicaeae). I. Taxonomy and variation. Willdenowia 19:271-365

Snogerup S, Snogerup B, Phitos D et al (2001) The flora of Chios island (Greece). Bot Chron 14:5-199

Strid A (1970) Studies in the Aegean flora XVI. Biosystematics of the Nigella arvensis complex with special reference to the problem of non-adaptive radiation. Opera Bot 28:1-169

Strid A (1996) Phytogeographia Aegaea and the Flora Hellenica Database. Ann Naturhist Mus Wien 98(Suppl):279-289

Strid A, Tan K (eds) (1998) Flora and vegetation of North East Greece, including the islands of Thasos and Samothraki. Report of a student excursion from the University of Copenhagen May 17-31, 1997. Botanical Institute, Copenhagen

Tjørve E (2003) Shapes and functions of species-area curves: a review of possible models. J Biogeogr 30:827-835

Triantis KA, Mylonas M, Whittaker RJ (2008) Evolutionary species-area curves as revealed by single-island endemics: insights for the inter-provincial species-area relationship. Ecography 31:401-407

Trigas P, Iatrou G (2006) The local endemic flora of Evvia (W Aegean, Greece). Willdenowia 36:257-270

Turland NJ (1992) Studies on the Cretan flora 2. The Dianthus juniperinus complex (Caryophyllaceae). Bull Br Mus Bot 22:165-169

Turland N, Chilton L (2008) Flora of Crete: supplement II, additions 1997-2008. http://www. marengowalks.com/fcs.html. Accessed 1 Oct 2009

Turland NJ, Chilton L, Press JR (1993) Flora of the Cretan area. Annotated checklist and atlas. London

Tzanoudakis D, Panitsa M, Trigas P (2006) Floristic and phytosociological investigation of the Aegean islands and islets: Antikythera islets'group (SW Aegean area, Greece). Willdenowia 36:285-301

Whittaker RJ, Fernandez-Palacios JM (2007) Island biogeography. Ecology, evolution and conservation, 2nd edn. Oxford University Press, Oxford

Willerslev E, Hansen AJ, Klitgaard Nielsen K et al (2002) Number of endemic and native plant species in the Galapagos Archipelago in relation to geographical parameters. Ecography 25:109-119 